\title{
Primórdios do futebol em Goiás, 1907-1936
}

\section{Early football in the State of Goiás, 1907-1936}

\section{Cleber Dias*}

\begin{abstract}
Resumo
O objetivo desse trabalho é investigar a história do futebol em Goiás entre os anos de 1907 e 1936, período que corresponde aos momentos iniciais da organização deste esporte na região. Diferente das imagens de isolamento e vazio cultural que geralmente marcam Goiás, este trabalho postula que um desenvolvimento esportivo relativamente precoce realizou-se ali, sobretudo a partir de meados da década de 1910, intensificando-se e alastrando-se nas duas décadas seguintes. Esse processo foi marcado pelas condições sociais particulares da região, sobretudo seu peculiar processo de modernização, que se combinou com características tradicionais de uma sociedade ainda fundamentalmente rural e agrária. Foi também o resultado de relacionamentos e influências vindas não apenas de regiões metropolitanas, mas especialmente de outras cidades do interior, mobilizando agentes locais, que se engajaram ativamente na disseminação do futebol em Goiás.
\end{abstract}

Palavra-chave: História. História Regional. Esporte. Futebol. Goiás.

\begin{abstract}
This work aims at researching the history of football in the state of Goiás between the years 1907 and 1936, time of the early moments of the organization this sport in the region. Unlike the images of isolation and cultural void, usually related to Goiás, this work argues that a relatively early sport development took place there, specially from mid-1910s, intensifying and spreading up for the next two decades. This process was marked by the peculiar social conditions of the region, especially the peculiar process of modernization, which, mixed with the traditional characteristics of a society still mainly rural and agricultural. It was also the result of influences and relationships coming not only from metropolitan regions but especially from other inner cities, mobilizing local actors, who had actively engaged in spreading football in Goiás.
\end{abstract}

Keywords: History; Regional History; Sport; Football; Goiás.

\footnotetext{
* Doutor em Educação Física pela Unicamp. É professor da Universidade Federal de Minas Gerais. E-mail: cag.dias@bol.com.br
} 
O objetivo deste trabalho é investigar a história do futebol em Goiás entre os anos de 1907 e $1936 .{ }^{1}$ Essa periodização circunscreve, de um lado, os primeiros registros da prática deste esporte em Goiás e, de outro, a assimilação definitiva do novo costume como um hábito cotidiano, amplamente disseminado por vários segmentos sociais. Depois disso, em 1937, a capital goiana foi oficialmente transferida da Cidade de Goiás para Goiânia, simbolizando o ápice de um processo de transformações sociais, políticas, econômicas e culturais que se desenrolavam em Goiás por duas ou três décadas, ${ }^{2}$ quando uma dinâmica de funcionamento do campo esportivo mostrar-se-ia já desenvolvida mais solidamente. A partir de então, equipes, ligas e federações adquiriram mais perenidade institucional; jogadores, árbitros, técnicos e dirigentes tenderam, progressivamente, a se profissionalizarem. Analisar o modo como se construiu esta dinâmica é o objetivo deste trabalho.

Região historicamente marcada pelo signo do atraso e do isolamento, Goiás foi, e em certo sentido é ainda, representado como antítese da modernidade; um "vazio cultural”, razão pela qual práticas e costumes modernos, tais como os esportes, seriam, em tese, desconhecidos ali, ao menos até anos avançados do século XX. ${ }^{3}$ O desenvolvimento histórico do esporte, afinal, geralmente se fez acompanhar por um conjunto de outras transformações civilizadoras, que simbolizava sua prática como um ideário de progresso urbanístico e modernização dos costumes. ${ }^{4}$ Não é outro o motivo pelo qual propagandas da bola Apollo, empenhadas em convencer potenciais consumidores de que era esta a mais conhecida bola de football do Brasil em 1921, destacava que “bolas 'APOLLO' estão sendo jogadas nos lugares

\footnotetext{
${ }^{1}$ Este estudo contou com apoio do CNPq (Processo 481118/2011-0). A pesquisa realizou-se nos acervos do Arquivo Histórico Estadual de Goiás, no Instituto de Estudos e Pesquisas Históricas do Brasil Central, no Arquivo Frei Simão Dorvi e na Biblioteca Nacional do Rio de Janeiro. Além dos funcionários dessas instituições, agradeço também aos estudantes da Universidade Federal de Goiás, que prestaram valioso auxílio em diferentes momentos desta pesquisa: Vinicius Aires, Thamara Jacob, Georgia Lehnen, Cristina Kagueyama, Pollyana de Paula e Tatiana Tucunduva.

${ }^{2}$ CHAUL, Nasr Fayad. A construção de Goiânia e a transferência da capital. Goiânia: Ed. da UFG, 1999.

${ }^{3}$ A respeito da imagem histórica de atraso e decadência de Goiás, ver CHAUL, Nasr Fayad. Caminhos de Goiás: da construção da decadência aos limites da modernidade. 2 ed. Goiânia: Ed. da UFG, 2010; GARCIA, L. F. Goyaz: uma província do sertão. Goiânia: Ed. da PUC GO / Cânone, 2010; MAIA, João Marcelo Ehlert. Governadores de ruínas: os relatos de viagem de Couto Magalhães e Leite Moraes. Estudos Históricos, Rio de Janeiro, n. 40, p. 3-23, jul./dez. 2007; KARASCH, Mary. The periphery of the periphery? Vila Boa de Goiás, 1780-1835. In: DANIELS, Christine; KENNEDY, Michael V. (eds.). Negotiated Empires: Centers and Peripheries in the Americas, 1500-1820. New York: Routledge, 2002, p. 143-170.

${ }^{4}$ Sobre a relação entre esporte e projetos civilizatórios, ver LUCENA, Ricardo. 0 esporte na cidade. Campinas: Autores Assocaidos, 2001; MELO, Victor. Cidadesportiva: primórdios do esporte no Rio de Janeiro. Rio de Janeiro: Relume-Dumará/Faperj, 2001; PEREIRA, Leonardo Affonso de Miranda. Footballmania: uma história social do futebol no Rio de Janeiro, 1902-1938. Rio de Janeiro: Nova Fronteira, 2000.
} 
mais afastados: nos planaltos de Goyaz, nos sertões de Matto Grosso". ${ }^{5}$ Associações simbólicas desse tipo pretendiam confirmar a popularidade do produto apelando, justamente, para o imaginário a respeito desses lugares, afinal, até mesmo ali, nos longínquos sertões de Goiás e Mato Grosso, seriam conhecidas as suas vantagens (ver Imagem 1).

Imagem 1 - Propaganda das bolas Apollo (1921)

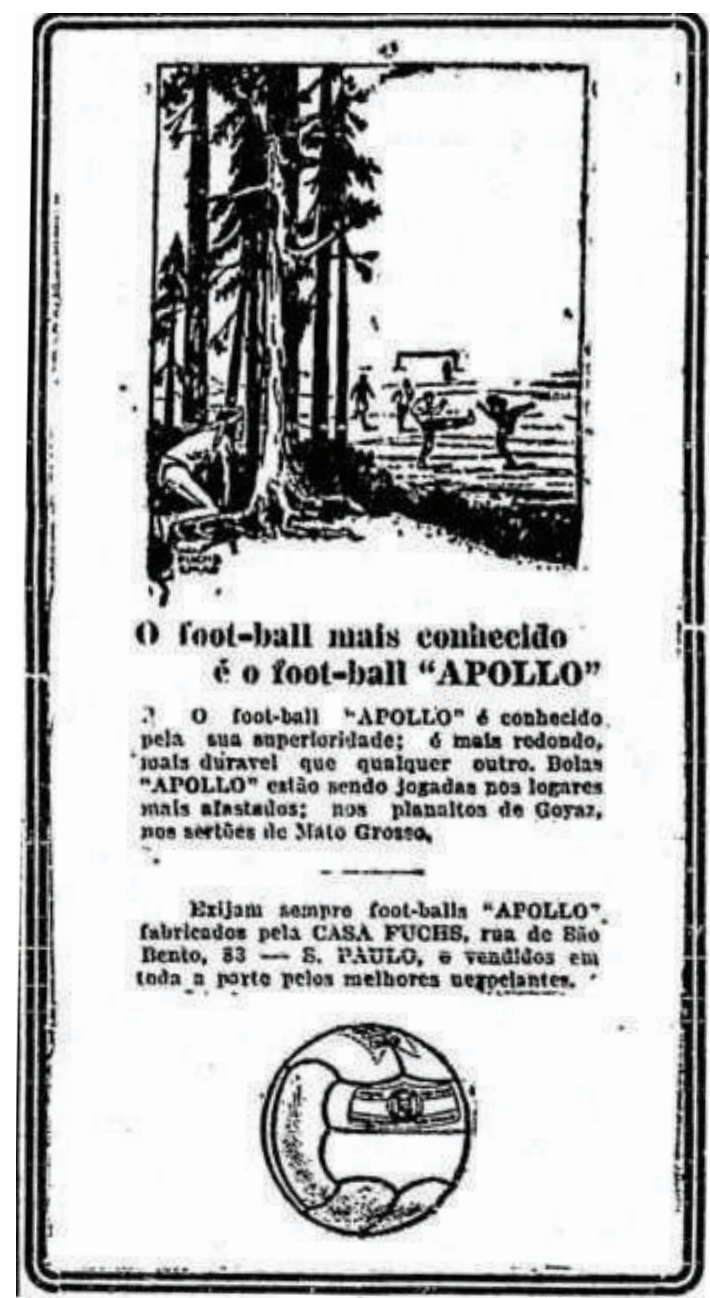

Fonte: Folha da Noite, São Paulo, 03 set. 1921, n. 168, p. 3.

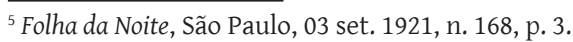


Operações discursivas assim não foram exclusivas a propagandas de materiais esportivos, tampouco se iniciaram nesse período. De um modo geral, Goiás sempre fora susceptível a imagens de atraso e isolamento. Todavia, no que diz respeito aos esportes, conforme tentarei demonstrar, a população de Goiás, mesmo que geograficamente afastada dos grandes centros urbanos, não ficou alheia a transformações comportamentais decorrentes dessas práticas. À sua maneira, Goiás também experimentou uma nova excitabilidade ligada aos modernos costumes chamados "sports", que de maneira até relativamente precoce se tornaram importantes elementos da sociabilidade goiana.

\section{História do futebol em Goiás}

Em Goiás, desde 1907 tem-se notícias dos primeiros jogos de futebol. Segundo memórias de Ofélia Sócrates do Nascimento, "em 1907 o Largo do Chafariz, tão quieto, tão tranquilo, passou a ser agitado pela algazarra dos jogadores de futebol". ${ }^{6}$ Basicamente, um grupo de estudantes do Lyceu de Goiás organizava as partidas, influenciados por colegas que vinham de outras cidades, e incentivados, a partir de 1908, por Archie Macintyre, um pastor protestante inglês que esteve na cidade antes de edificar missão evangelizadora entre os índios do rio Araguaia. ${ }^{7}$ Segundo depoimento de Walter Sócrates do Nascimento, um dos que participava dos jogos à época:

O terreno era íngreme. Não tinha grama e sim um cascalho fino. Não tinha trave e sim duas varas fincadas. O campo, inicialmente, não obedecia às regras. Era pequeno, pois começamos com seis jogadores de cada lado. Sem uniformes e sem chuteiras. Jogávamos com a roupa do corpo. As marcações do campo eram feitas com riscos no chão. Os treinos eram feitos na parte da tarde em qualquer dia da semana. ${ }^{8}$

Eram partidas improvisadas, como se vê, jogadas com "bola de mangaba”, contando com, no máximo, 10 ou 12 jogadores. Com o tempo, contudo, a prática parece ter conhecido relativo sucesso. Em 1908 já se realizavam partidas entre 22 jogadores, com gols de sarrafo, campo de terra demarcado, camisas diferenciadas entre as equipes, supervisão de "árbitros" e até mes-

\footnotetext{
${ }^{6}$ MONTEIRO, Ofélia Sócrates do Nascimento. Remiscências: Goiás d'antanho, 1907-1911. Goiânia: Oriente, 1974, p. 81.

${ }^{7}$ GODOI, Albatenio. Do meu tempo. Goiânia: UFG, 1969, p. 273-274.

${ }^{8}$ Apud. ALVES FILHO, João Batista. Arquivos do futebol Goiano. Goiânia: O Popular, 1982, p. 27.
} 
mo a adoção do velho esquema tático 2-3-5. ${ }^{9}$ Nesse momento, entre 1909 e 1911, a equipe já teria nome inclusive: Goyaz Football Club ou Sport Club Goyano Athletico, de acordo com a fonte. Jornais da época registravam mesmo uma "animação da vida sportiva". Além das corridas de cavalo no campo do João Francisco, tradicional local de muitas festividades, notava-se também "exercícios de football e outros divertimentos físicos". Irretorquivelmente, como protagonista aparecia a "mocidade acadêmica e ginasial [...] a par do espírito de desenvolverem as forças do corpo, para que gozem mens sana in corpore sano - equilíbrio indispensável à saúde do homem civilizado". ${ }^{10}$

Todavia, a prática não parece ter se disseminado. Apenas na década de 1920 um movimento mais generalizado ao redor do esporte seria deflagrado na Cidade de Goiás. Muitos dos envolvidos com o jogo à época, sobretudo os mais engajados, viajaram para o Rio de Janeiro, São Paulo e Minas Gerais a fim de concluírem seus estudos em engenharia, direito ou medicina, como era comum. Oportunidades para o lazer da população na capital de Goiás, além disso, existiam, mas eram ainda limitadas. Conforme dissera Jaime Câmara, em suas memórias sobre a vida na cidade nesse período, "Goiás não era de muita festa nessa época". ${ }^{11}$ As diversões, de modo geral, eram relativamente poucas, restringindo-se, basicamente, a bailes e saraus particulares, além de festas e procissões religiosas. Ocasionalmente, aconteciam apresentações teatrais, musicais ou circenses, promovidas, muitas vezes, por artistas itinerantes.

O viajante inglês Arnold Henry Savage Londor, que esteve na cidade em 1911, registrou suas impressões sobre a vida do local. Segundo ele, tratava-se de lugar bonito, mas morto, "uma cidade medieval", nas palavras dele, sem pessoas, sem indústria, sem negócios, nem comércio, onde os dias arrastavam-se tediosamente. Seus habitantes pareciam-lhes "apáticos" e "ultraconservadores em suas ideias". ${ }^{12} \mathrm{O}$ futebol, nesse contexto, mesmo que praticado regularmente, o que é incerto, não seria, de todo modo, muito mais que um passatempo de crianças, um mero "bate-bola", como se dizia.

Claro que tais diagnósticos são discutíveis. Em determinadas circunstâncias, uma vida social efervescente também podia notar-se em Goiás, especialmente em outros pontos do estado. Diferindo do padrão de outras

\footnotetext{
${ }^{9}$ Ibidem.

${ }^{10}$ Vida sportiva. Goyaz, Goyaz, n. 1017, 1908, p. 2 apud. TAVARES, Milena Bastos. Memória da Associação Atlética União Goiana. Goiás: Instituto do Patrimônio Histórico e Artístico Nacional, 2010, p. 42.

${ }^{11}$ CÂMARA, Jaime. Nos tempos de frei Germano. Goiânia: Cultura Goiana, 1974, p. 35

${ }^{12}$ SAVAGE-LANDOR, A. Henry. Across unknow South America. London: Hodder and Stoughton, 1913.
} 
regiões, a capital goiana não era a cidade mais populosa ou economicamente mais dinâmica de Goiás. Outras cidades registravam florescimento urbano mais intenso, o que favorecia a criação de condições de possibilidade para a emergência histórica do futebol em outros patamares, isto é, para além de um desinteressado divertimento juvenil.

Enquanto a capital goiana contabilizava pouco mais de 13 mil almas por volta de 1910, cidades como Catalão já atingiam, na mesma época, população superior a 30 mil pessoas. ${ }^{13}$ A proximidade e o intenso intercâmbio (cultural, social e econômico) com cidades do Triângulo Mineiro estimulava seu crescimento em vários aspectos, incluindo o esportivo. A cidade de Uberaba, particularmente, atendida por linhas da Companhia Mogiana de Estradas de Ferro desde 1889, testemunhava práticas esportivas desde os fins do século XIX. Por volta de 1863 têm-se já registros da realização regular de corridas de cavalo. Na transição entre os séculos XIX e XX, sabe-se que os uberabenses conheciam a bocha, o bilhar, o ciclismo, a patinação, os exercícios de ginástica e as rodas de peteca.

Por volta de 1903, padres Maristas assumiram a direção do Ginásio Diocesano de Uberaba, e entre as práticas promovidas pelos religiosos estava o "bate-bolão", "pálido arremedo do rugby", segundo avaliação de Hildebrando Pontes. ${ }^{14}$ Mesmo assim, alunos do Ginásio foram se engajando nos jogos. Por volta de 1905, um grupo de alunos conseguiu comprar, em São Paulo, um guia e bolas de futebol, além de formarem um time, chamado Clube de Futebol. Apesar do nome e do contato com as regras do association, o time praticava um jogo diferente, valendo-se ainda das mãos. Ao mesmo tempo, uberabenses que haviam estudado em São Paulo, nomeadamente em Campinas, no Colégio São Luís, começavam a voltar para Uberaba nessa época, trazendo consigo mais entusiasmo pelo esporte bretão, bem como mais noções de regras, técnicas e táticas. Em 1906, um grupo de uberabenses cotizou-se para comprar uma bola de futebol em São Paulo. Eles pretendiam formar um clube de futebol, o que acabou não ocorrendo. Mesmo assim, segundo conclusões de Hildebrando Pontes, "o movimento pró-futebol ia se acentuando em Uberaba". Segundo ele, "tanto dentro como fora do Ginásio, até então, nada organizado havia a que se pudesse dar o nome de futebol.

\footnotetext{
${ }^{13}$ AZEVEDO, Francisco Ferreira dos Santos. Annuario histórico, geographico e descriptivo do Estado de Goyaz para 1910. Brasília: Secretaria do Patrimônio Histórico e Artístico Nacional, 1987.

${ }^{14}$ PONTES, Hildebrando. História do futebol em Uberaba. Uberaba: Academia de Letras de Uberaba, 1972, p. 34.
} 
Entretanto, a população de Uberaba não mais ignorava que existia uma espécie de diversão esportiva denominada futebol". ${ }^{15}$

Em 1908, uma área atrás do Ginásio Diocesano foi adquirida para a realização de evoluções militares. O local acabou servindo também como campo de esportes, usado para partidas de futebol entre os times "branco-preto" e "verde-amarelo", formados por alunos do colégio. Os jornais uberabenses da época falavam desses jogos como "animados matches de futebol no sport field do Ginásio”. Em abril de 1909, segundo notícia publicada no jornal o Paladino, fora "animadíssimo e muito concorrido" o jogo de futebol realizado ali. De acordo com a notícia: "os espectadores, compostos de pessoas mais conspícuas da nossa sociedade, apreciaram com prazer e entusiasmo a maestria com que os jovens jogadores de parte a parte disputavam o gol". ${ }^{16}$

Diante do sucesso das atividades, em 1910, a Reitoria do Ginásio Diocesano instituiu um campeonato interno, a "Taça Jeanne D'Arc" [sic]. Paralelamente, outros clubes de futebol surgiam na cidade, como o Atlético Futebol Clube e o Mogiana Futebol Clube; este último, formado por ajudantes de tráfego, chefes de depósitos e outros funcionários da Companhia Mogiana de Estrada de Ferros, alguns com passagens por clubes como o Comércio Futebol Clube, de Campinas. Em 1911, por ocasião de uma exposição agropecuária que aconteceu naquele ano em Uberaba, o presidente da municipalidade sugeriu aos times do Ginásio que organizassem uma seleção para enfrentar uma equipe de Araguari. Surgia assim o Diocesano Futebol Clube, um dos primeiros times a mobilizar grandes contingentes para a prática do futebol na cidade. Na sua primeira partida, o time venceu seus adversários de Araguari por 2 x 0, logo passando a ser reconhecido como "o invencível". Segundo Hildebrando Pontes, "o garbo com que os rapazes desse eleven se exibiram pelas ruas de Uberaba [após essa partida], despertou entre a mocidade um entusiasmo desusado, impelindo todos a um intenso movimento pró-futebol". ${ }^{17}$

Nessa época, os times multiplicaram-se rapidamente: Tiradentes, Comercial, Floriano Peixoto, Duque de Caxias, Coronel Sampaio, Guarani. Consolidava-se, enfim, "um movimento caloroso, vibrante em prol da definitiva e benéfica implantação do esportismo entre nós". ${ }^{18}$ Os uberabenses

\footnotetext{
${ }^{15}$ Ibidem, p. 38.

${ }^{16}$ Ibidem, p. 49.

${ }^{17}$ Ibidem, p. 39.

${ }^{18}$ Ibidem.
} 
agitavam-se já por causa dos jogos de futebol: cogitavam a formação de uma liga, planejavam a organização de um campeonato e testemunhavam a fundação de um jornal esportivo (em 1918).

O fanatismo pelo futebol atingiu a um grau muito elevado. A terminologia técnica torna-se familiar a todos. Ninguém mais diz coice; porque chute é mais elegante e moderno. As palestras com facilidade tombam para o lado do jogo e se alongam por tempo quase indefinido. Os fabricantes de bebidas dão a uma nova marca de sua fabricação o nome de Licor Futebol. ${ }^{19}$

Toda esta ambiência parece ter influenciado várias cidades goianas, notadamente as do Sul e Sudeste do estado. Ao longo da década de 1910, alguns jovens de cidades como Itaberaí, Itumbiara, Catalão e Morrinhos, deslocavam-se para Uberaba a fim de estudar no Ginásio Diocesano daquela cidade, "o mais famoso do Brasil Central", segundo memórias de Joaquim Rosa. ${ }^{20}$ De fato, o Ginásio Diocesano parece ter desempenhado papel importante sobre as elites goianas. Por volta de 1910, jornais de Goiás já publicavam propagandas anunciando as vantagens da escola. Além da "educação esmerada", da "pensão módica" ou da "situação excepcional para comunicações e viagens", destacava-se também os "grandes pátios de recreio e vastíssimo campo de esportes para jogos escolares". ${ }^{21}$

No Ginásio Diocesano, muitos jovens goianos aprenderam a jogar futebol, como foi o caso, por exemplo, de Edmundo Pinheiro de Abreu, natural de Itumbiara e seu estudante no fim da década de 1910, tendo atuado, inclusive, no ataque da equipe da escola. De volta a Goiás, alguns desses jovens acabaram atuando ativamente no esporte do estado. Edmundo Pinheiro de Abreu, para seguirmos com o exemplo, foi um grande entusiasta do esporte ao longo de toda a vida. Na juventude, esteve entre os primeiros jogadores de futebol de sua cidade natal. Já na nova capital de Goiás, Goiânia, teve ativo envolvimento com o Goiás Futebol Clube (um dos principais clubes do Estado atualmente), exercendo inúmeros cargos na administração do clube, como o de presidente do Conselho Consultivo, além de ter participando da direção da Federação Goiana de Futebol (criada em 1944). ${ }^{22}$

Por causa da sua situação de entreposto comercial obrigatório entre Goiás, São Paulo e Rio de Janeiro, Uberaba acabava funcionando como

\footnotetext{
${ }^{19}$ Ibidem, p. 40.

${ }^{20}$ ROSA, Joaquim. Por esse Goiás afora. Goiânia: Cultura Goiana, 1974, p. 24.

${ }^{21}$ Gymnasio Diocesano de Uberaba. O Jatahy, Jatahy, 15 mar. 1910, n. 10, p. 2.

${ }^{22}$ SILVA, Cristiano. Corações esmeraldinos. Goiânia: Ed. do Autor, 2007; ALVES Filho, op. cit., p. 145.
} 
ponto de referência simbólico e geográfico para toda a região, a "Princesa do Sertão", como era conhecida; lugar de intermediação entre a modernidade civilizada do litoral e a ruralidade atrasada do sertão. No início dos anos 20, quando jovens de Anápolis estavam interessados em praticar o futebol, era até Uberaba que viajavam para comprar bolas, chuteiras e uniformes. ${ }^{23}$

Para além do esporte, as relações entre as cidades fronteiriças de Goiás e Minas Gerais eram tão intensas que Wilson Cavalcanti Nogueira chega a afirmar que "a partir da presença da Mogiana em Araguari, Goiás passara a ter realmente três capitais. Uma política, em Vila Boa, e duas econômicas, em Araguari e Uberlândia". ${ }^{24}$ Em 1910, jornais de Catalão já noticiavam "a chegada constante de novo pessoal" e até "a falta de casas para aluguel", tudo por causa da aproximação da linha férrea, que começava a estender seus trilhos rumo ao planalto goiano, conforme os próprios contemporâneos diagnosticavam..$^{25} \mathrm{Em} \mathrm{1911,} \mathrm{o} \mathrm{intendente} \mathrm{municipal} \mathrm{da} \mathrm{cidade} \mathrm{contra-}$ tou serviço de energia elétrica, ao mesmo tempo em que anunciou o início da construção da sua primeira linha telegráfica, inaugurada no ano seguinte. Em 1913, as primeiras locomotivas da Estrada de Ferro Goiás atravessavam a ponte sobre o Rio Paranaíba, estabelecendo, finalmente, ligação férrea entre Goiás e Minas Gerais. Sintomaticamente, no mesmo ano fundou-se o Catalão Futebol Clube, que depois se tornaria uma potência futebolística da região: o Leão do Cerrado. A estrada de ferro, em suma, prenunciava a chegada do progresso nos sertões de Goiás, o que em certa medida também dizia respeito aos esportes.

De acordo com Barsanufo Borges, nas primeiras décadas do século XX, Goiás encontrava-se submerso num processo de profundas mudanças. Para o autor, "a Estrada de Ferro desempenhou um papel fundamental como elemento promotor dessas transformações". ${ }^{26}$ Em 1920, Goiás já era o quarto maior produtor de arroz do Brasil, produzindo mais de 20 mil toneladas do produto por ano. Na mesma época, as importações totais do Estado superavam a marca de 10 mil toneladas, enquanto as exportações por meio da ferrovia, especificamente, ultrapassavam 12 mil toneladas. ${ }^{27}$ Para Ana Lúcia da Silva, no mesmo sentido, "a penetração da estrada de ferro assinalou um

\footnotetext{
${ }^{23}$ FERREIRA, Haydée Jayme. Anápolis: sua vida, seu povo. Brasília, 1981.

${ }^{24}$ NOGUEIRA, Wilson Cavalcanti. Pires do Rio: marco da historia de Goiás. Goiânia: Roriz, 1977, p. 28.

${ }^{25}$ Gazeta de Catalão, 20 dez. 1910, apud., CHAUD, Antônio M. J. Memorial do Catalão. Goiânia: Ed. do Autor, 2000.

${ }^{26}$ BORGES, Barsanufo Gomes. O despertar dos dormentes. Goiânia: Ed. da UFG, 1990, p. 109.

${ }^{27}$ Ibidem, p. 100.
} 
marco na integração de Goiás na economia de mercado, uma vez que permitiu acelerar o processo de compra e venda de mercadorias [...] causando uma verdadeira revolução nos padrões de consumo e comportamento da população". ${ }^{28}$

Desde os meados do século XIX a expansão da economia cafeicultura em São Paulo, articulada ao crescimento urbano-industrial da região, criava demandas para incorporação de novas áreas para o oferecimento de alimentos e o consumo de manufaturados. Ao mesmo tempo, a concentração da propriedade fundiária e a incorporação extensiva de novas áreas de plantio expulsavam antigos moradores e dificultavam a absorção de imigrantes, obrigados, então, a se deslocarem para regiões periféricas. O Triângulo Mineiro, em primeiro lugar, e as fronteiras Sul de Goiás, em segundo, estavam, assim, na rota de expansão das frentes pioneiras. ${ }^{29}$ Para Goiás, uma das consequências desse processo foi a expansão contínua de sua economia e demografia após 1910. A partir de 1917, mais especificamente, registram-se crescimentos progressivos nos índices de exportação de produtos agropastoris em Goiás. Paralelamente, depois de 1900, a população da região chegou a crescer acima da média nacional. Entre 1900 e 1920, a média anual de crescimento populacional em Goiás foi de 3,5\%, enquanto no Brasil, de modo geral, esse índice foi de $2,7 \% .^{30}$

Não por acaso, nessa época parece ter se intensificado, entre parte da população goiana, o sentimento de se estar vivendo grandes mudanças. Em Anápolis, quando a colheita de café já atingia a marca de 300 mil arrobas, sob o efeito de inovações como o cinema ou aparelhos de telefonia sem fio, recebendo irradiações do Rio de Janeiro, São Paulo e Buenos Aires, falava-se da entrada de uma "nova vida de cidade moderna". Segundo dizia-se, "ali, tudo participa do afluxo de desenvolvimento. Comércio, lavoura e indústria [...] Estar em Anápolis ouvindo um concerto na Argentina, já representa alguma

\footnotetext{
${ }^{28}$ SILVA, Ana Lúcia da. A revolução de 30 em Goiás. 2 ed. Goiânia: Cânone, 2005, p. 97.

${ }^{29}$ José de Souza Martins propõe uma diferenciação entre fontes de expansão e frentes pioneiras. Embora o autor aponte para a noção de frentes de expansão como a mais "rica e apropriada para a reflexão sociológica", dado que é esta a situação que melhor caracteriza o confronto com uma alteridade por vezes radical, no caso desse trabalho, especificamente, é mesmo a ideia de frentes pioneiras o que parece mais diretamente relacionado ao processo histórico de desenvolvimento e disseminação de esportes em Goiás. Pois, ainda segundo Martins, "a concepção de frente pioneira compreende implicitamente a ideia de que na fronteira se cria o novo, nova sociabilidade, fundada no mercado e na contratualidade das relações sociais" (MARTINS, José de Souza. O tempo da fronteira: retorno à controvérsia sobre o tempo histórico da frente de expansão e da frente pioneira. Tempo Social, São Paulo, vol. 8, n. 1, p. 25-70, mai. 1996, p. 33 e 29, respectivamente).
}

${ }^{30}$ SILVA, op. cit. 
coisa". ${ }^{31}$ Na capital do estado, no mesmo sentido, comentando as inovações que afetavam a vida social da cidade, nomeadamente o avião, as festas, as sorveterias elétricas e as companhias de teatro, o cronista Lívio fixara bem essa perspectiva. Segundo ele, "de alguns tempos para cá, Goyaz tem vivido uma vida nova, intensa, moderna, que já nos dá o direito de reclamar um lugarzinho no código das 'grandes cidades". ${ }^{32}$

\section{Esporte e modernização em Goiás}

Dinamismo econômico e crescimento demográfico, portanto, parecem ter sido algumas das principais circunstâncias históricas necessárias ao desenvolvimento do futebol em terras goianas. A medida, pois, que elas se tornavam mais frequentes, multiplicavam-se também os times e os jogos de futebol. Até o fim da década de 1910, a organização de times e a realização de partidas foram registradas, pelo menos, em Anápolis, Pirenópolis e Catalão. No alvorecer da década seguinte, intensificou-se a disseminação do jogo. Nessa época, o Catalão Futebol Clube já possuía um terreno para a construção de uma praça de esportes, ${ }^{33}$ onde outros times da cidade, como o Operário, o Americano e o Brasil Futebol Clube debater-se-iam contra o Leão do Cerrado. ${ }^{34}$

Em 1923, segundo registros de Péricles Xavier Rebello, jogos de futebol já se realizavam em cidades do norte de Goiás (atualmente Tocantins), notadamente em Natividade e Porto Nacional. Segundo Rebello, ali, "o futebol se difundiu graças aos estudantes, que o conheciam no estado da Bahia e o implantavam nos rincões goianos". ${ }^{35}$ Em 1924, partidas entre os moradores da Rua Direita contra o Resto já se realizavam em Jaraguá, ${ }^{36}$ ao mesmo tempo em que se criava a primeira equipe de futebol em Pires do Rio, que encontraria nos times de Iparemi seus principais adversários. Conhecida como a "sala de visita de Goiás”, por causa, justamente, do seu desenvolvimento, Ipameri

\footnotetext{
${ }^{31}$ Annapolis e seu progresso. Novo Horizonte, Catalão, 06 jun. 1926, n. 213, p. 3.

${ }^{32}$ LÍVIO. Coisas da capital. Correio Official, Goyaz, 05 fev. 1932, n. 2118, p. 8.

${ }^{33}$ RAMOS, Cornélio. Catalão de ontem e de hoje: curiosos fragmentos de nossa história. Catalão: Kalil, 1984. p. 74.

${ }^{34}$ Foot-ball. Novo Horizonte, Catalão, 04 fev. 1926, n. 197, p. 3; Foot-ball. Novo Horizonte, Catalão, 11 ago. 1928, n. 313, p. 2.

${ }^{35}$ REBELLO, Péricles Xavier. Usos e costumes de Goiás: estudos e interpretação de 1900-1980. Goiânia: Gráfica e Editora Líder, 1987, p. 98.

${ }^{36}$ ALVES FILHO, op. cit., p. 43.
} 
testemunhava "festas sportivas" desde essa época; eventos realizados sempre com o "máximo brilhantismo", conforme informava telegrama do Major Favilla, comandante do 6ํㅡㄹ Batalhão de Caçadores, responsável por algumas dessas atividades. ${ }^{37} \mathrm{Em}$ Itumbiara, de maneira análoga, criava-se, nessa época, o Santa Rita Futebol Clube. ${ }^{38} \mathrm{Em} 1925$, partidas de futebol já aconteciam até mesmo entre índios, na ilha do Bananal. A presença de funcionários do Serviço de Proteção aos Índios serviu como ocasião para a disseminação do novo jogo entre os "silvícolas" do Brasil Central. ${ }^{39}$

Nessa época, cidades por todo o estado de Goiás conheceriam em número crescente suas equipes de futebol: Bela Vista Futebol Clube, Atlético Belavistense, Bonfim Esporte Clube, Leopoldo de Bulhões Futebol Clube, Vianápolis Esporte Clube, Associação Atlética Rio Verde, Rio Bonito Futebol Clube, foram algumas das equipes criadas na ocasião. ${ }^{40}$ Enquanto isso, na capital, fundava-se a Associação Athlética União Goyana ${ }^{41}$, que ocuparia papel importante no futebol do estado até meados da década seguinte. Outros times, como os dos Sargentos, dos Operários, do Tiro 78, do Ibsen Caiado, do Anhauguera, do América e do Brasil Central também concorreriam para o preenchimento cada vez mais frequente e regular de algumas horas de lazer das tardes de domingo no período. ${ }^{42}$ Iniciava-se, assim, a época em que já não se podia encontrar "nenhuma povoação do interior e mesmo as diversas fazendas espalhadas em nossas zonas rurais sem o infalível campo de jogo". ${ }^{43}$ Iniciava-se, enfim, a época em que quase toda a população de algumas cidades e regiões circunvizinhas cercaria os quatro lados dos campos de futebol nos dias de domingo. ${ }^{44}$

Termômetro da capacidade de irradiação das novas práticas, a presença das mulheres nos grounds de football já se fazia notar nestas ocasiões. No início, eram "senhorinhas" que cumpriam o papel de madrinhas das

\footnotetext{
${ }^{37}$ Ipamery. Correio Official, Goyaz, 11 set. 1926, n. 1208, p. 8.

${ }^{38}$ FERREIRA, Rogério Arédio. Recortes de Itumbiara. Goiânia: Kelps, 2009.

${ }^{39} \mathrm{Cf}$. DIAS, Cleber. A Igreja, o Estado e a bola: história do esporte entre os índios do Brasil Central. Pensar a Prática, Goiânia, vol. 15, n. 1, p. 148-175, jan./mar. 2012.

${ }^{40}$ Notas esportivas. Correio Official, 08 dez. 1932, n. 2623, p. 8 e Futebol no interior. Correio Official, Goyaz, 13 out. 1931 , n. 2029 , p. 8.

${ }^{41}$ Estatutos da Associação Athletica União Goyana. Correio Official, Goyaz, 23 out. 1930, n. 1762, p. 4-7.

${ }^{42}$ Foot-ball. Correio Official, Goyaz, 06 out. 1925, n. 1076, p. 3; Futebol. O democrata, Goyaz, 08 fev. 1930, n. 646, p. 3.

${ }^{43}$ Deseja o público brasileiro lavrar a sentença condenatória do futebol. Folha de Goyaz, Goiânia, 25 jan. 1945, n. 250, p. 6.

${ }^{44}$ ALVES FILHO, op. cit., p. 43.
} 
equipes em disputa. Com o tempo, no entanto, o envolvimento de algumas mulheres com as partidas as colocaria mais ativamente no cenário esportivo, mas não ainda como jogadoras, o que demoraria algumas décadas mais, mas como "torcedoras" - bastante participativas por sinal. Segundo Rebello, "nos espetáculos de futebol, as mulheres torciam e, nessa torcida brigavam, falavam palavrões, quebravam suas sombrinhas ao baterem nas adversárias e jogavam pedras contra as mesmas". ${ }^{45}$

Outra ilustração desse processo de difusão do futebol em Goiás é o início e a rápida multiplicação de partidas entre equipes de diferentes cidades. Em 1923, depois de vencer vários jogos contra times da região, uma equipe de Catalão viajou até Anápolis para disputar uma partida contra um time que também tinha vencido partidas em Goiás, Inhumas, Morrinhos e Pirenópolis. A equipe de Catalão venceu por 2 x 0, motivo pelo qual é apontado às vezes como primeiro campeão goiano extraoficial. ${ }^{46}$

Jogadores de Jaraguá, por sua vez, além das equipes de Pirenópolis, costumavam enfrentar também times de Inhumas e Goiás. Nesses casos, “as tradicionais festas feitas em homenagem ao Divino Pai Eterno contavam com muitas atrações, dentre elas as cavalhadas, barraquinhas, banda de música e futebol". ${ }^{47} \mathrm{Na}$ Cidade de Goiás, a partir de 1925, aproximadamente, jogos desse tipo também já aconteciam entre os times locais e os de Itaberaí, Ipameri, Anápolis e Bela Vista. "Era um acontecimento marcante quando as duas agremiações [da Cidade de Goiás e de Itaberaí] se defrontavam, a ponto do jogo ser assistido pelo então governador do estado de Goiás, Brasil Caiado de Castro". ${ }^{48}$ Em 1926, até a cidade de Pouso Alto (atualmente Campos Belos),

\footnotetext{
45 REBELLO, op.cit., p. 97. O comportamento das mulheres na assistência de partidas de futebol parece ter sido bastante semelhante em diferentes regiões do país, bem como o modo de representá-lo. Nelson Rodrigues, em crônica de 1956, referindo-se, no entanto, a acontecimentos de princípios da década de 1910, dizia: "Naquele tempo tudo era diferente. Por exemplo: - a torcida tinha uma ênfase, uma grandiloquência de ópera. E acontecia esta coisa sublime: - quando havia um gol, as mulheres rolavam em ataques. Eis o que empobrece liricamente o futebol atual: - a inexistência do histerismo feminino" (RODRIGUES, Nelson. O berro impresso das Manchetes. Rio de Janeiro: Agir, 2007, p. 12). Para interessantes reflexões sobre a história da participação das mulheres no futebol brasileiro, ver FRANZINI, Fábio. Futebol é "coisa pra macho"? Pequeno esboço para uma história das mulheres no país do futebol. Revista Brasileira de História, São Paulo, v. 25, n. 50, p. 315-328, 2005; GOELLNER, Silvana Vilondre. Mulheres e futebol no Brasil: entre sombras e visibilidades. Revista Brasileira de Educação Física e Esporte, São Paulo, vol. 19, n. 2, p. 143-151, abr./jun. 2005; MALAIA, João M. C. Torcer, torcedores, torcedoras, torcida (bras.): 1910-1950. In: BUARQUE DE HOLLANDA, Bernardo Borges et al. A torcida brasileira. Rio de Janeiro: 7 Letras / Faperj, 2012, p. 53-85.

${ }^{46}$ RAMOS, op. cit.

${ }^{47}$ ALVES FILHO, op. cit., p. 38. O livro traz uma foto de Brasil Ramos Caiado ao lado de duas equipes de futebol, de Goiás e Itaberaí, datada de 1925. Cf. Ibidem, p. 32-33.

${ }^{48}$ Ibidem p. 32-3.
} 
relativamente distante do raio de transformações sociais e econômicas que afetavam a faixa sul do território goiano, "engalanou-se", conforme noticiou um jornal da época, para a partida de futebol contra equipe de Bela Vista, realizada, afinal, "sob uma atmosfera de verdadeiro delírio". ${ }^{9}$

Com o tempo, seriam cada vez mais frequentes essas partidas, chamadas "caravanas esportivas". Em 1931, por exemplo, uma equipe da cidade de Anápolis percorreu mais de 200 quilômetros para realizar uma partida contra equipe da cidade de Goiás. O jogo entre o Annapolis Sport Clube e a Associação Atletica União Goyana, "arrastou verdadeira multidão, ávida por assistir um sensacional embate"..$^{50}$ Segundo notícias, a partida foi "estupenda", "movimentada" e "cheia de lances emocionantes", com uma "concorrencia extraordinária, deixando agradabilíssima impressão". ${ }^{51}$ Daí em diante, por sinal, forte rivalidade desenvolver-se-ia entre equipes da capital e o Annapolis Sport Clube.

Por volta de 1928, até mesmo jogos fora dos limites de Goiás registrar-se-iam de maneira mais regular. Times de Catalão, pioneiramente, já o faziam até mesmo antes disso, sobretudo contra equipes do Triângulo Mineiro. Depoimentos como os de Cornélio Ramos, relembrando um acirrado campeonato regional nos idos de 1925, menciona uma partida entre o Catalão e o Araguari Futebol Clube. Segundo ele, "a torcida catalana comemorou ruidosamente a suada vitória [por 2 x 0]. A assistência era enorme dado à grande rivalidade que existia entre os dois times e mesmo devido às impiedosas derrotas sofridas anteriormente pelos goianos". ${ }^{52}$

Depois disso, contudo, partidas desse tipo, além de mais frequentes, passariam a ser retratadas como "um acontecimento auspicioso, que marca uma época nos anais da mocidade local". ${ }^{53}$ Rapazes do Tiro de Guerra 232, de Araguari, deslocavam-se até Catalão em trem especial. No campo do Catalão Futebol Clube encontravam, não raro, "grande número de torcedores”, como aconteceu na partida realizada durante os festejos de São João, em 1928. Desta feita, o time de Araguari demonstrou um "jogo de passes seguros". Alguns jogadores de Catalão, todavia, teriam deslumbrado o público em tiradas hábeis e sensacionais, "uma exibição magnífica de técnica e

\footnotetext{
${ }^{49}$ O Sport em Goyaz. Novo Horizonte, Catalão, 14 jul. 1926, n. 218, p. 3.

${ }^{50}$ Foot-Ball. Voz do Povo, Goyaz, 17 abr. 1931, n. 193, p. 2.

${ }^{51}$ Foot-Ball. Voz do Povo, Goyaz, 10 abr. 1931, n. 192, p. 3.

${ }^{52}$ RAMOS, op. cit., p. 74.

${ }^{53}$ Match amistoso de foot-ball. Novo Horizonte, Catalão, 04 de jul. 1928, n. 310, p. 1.
} 
resistência", o que acabou dando a vitória para os goianos por 2 x 1, em partida exibida mais tarde no cinema da cidade. ${ }^{54}$

Nessa época, jogos como entre o Morrinhos Esporte Clube, do lado goiano, e o Uberabinha Futebol Clube, do lado mineiro, já contavam com jogadores de São Paulo, Santos, Ribeirão Preto e Araguari, vindos especialmente para reforçarem as equipes das cidades ${ }^{55} \mathrm{~A}$ partir de meados dos anos 1930, intensificar-se-iam competições esportivas contra equipes de outros estados, Minas Gerais e São Paulo, sobretudo. Campeonatos esportivos entre cidades do interior desses estados reuniriam equipes de Pirajuhy, Piracicaba, Paraguassu, Araraquara, Franca, Mococa, Uberlândia, Ipameri, entre outras (ver Imagem 2).

Imagem 2 - Fotomontagem de campeonato esportivo entre cidades do interior (Uberlândia, 1937)

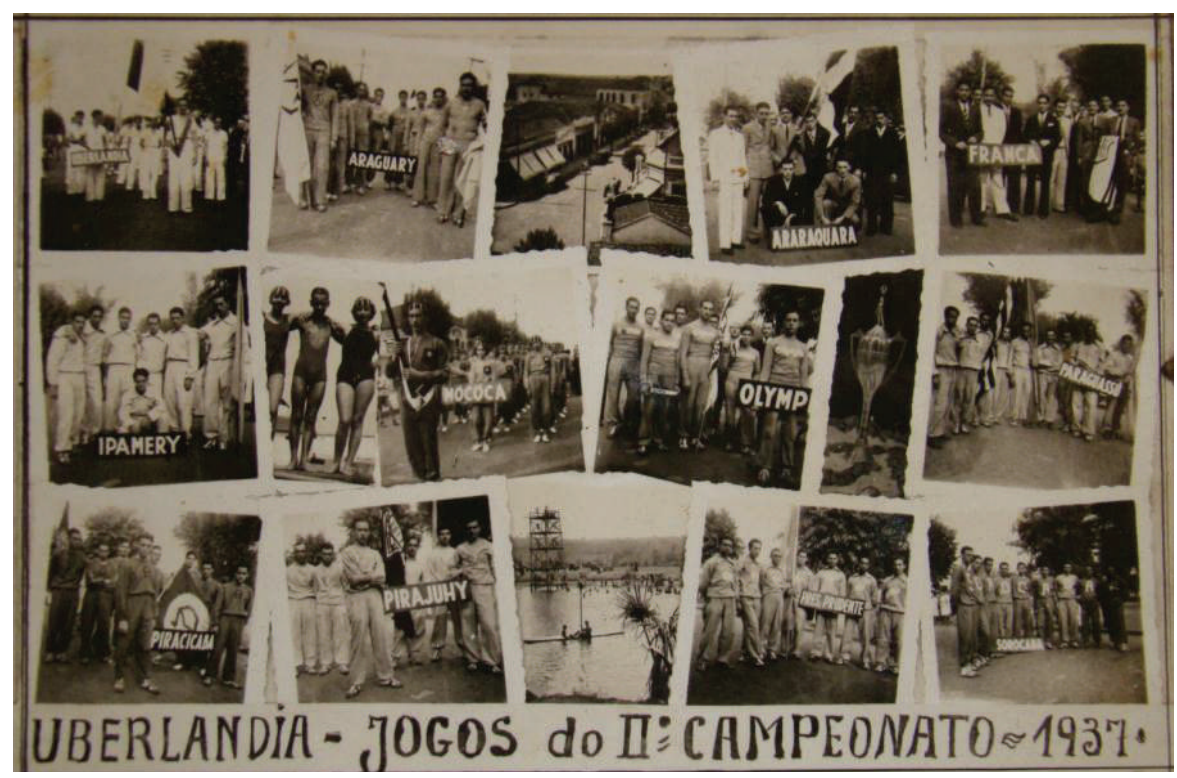

Fonte: Biblioteca Pública Municipal João Veiga. Autor desconhecido. Sem data.

Em 1936, pelo que se dizia ter sido a primeira vez, um clube de futebol de Anápolis, não medindo esforços para isso, trouxe, por ocasião dos festejos

\footnotetext{
${ }^{54}$ Grande jogo interestadual. Novo Horizonte, Catalão, 04 jul. 1928, n. 310, p. 4.

${ }^{55}$ Deseja o público brasileiro... Folha de Goyaz, Goiânia, 25 jan. 1945, n. 250, p. 6.
} 
da romaria do Bom Jesus, uma equipe do interior de São Paulo para uma disputa - da cidade de Ituvava, mais especificamente. No dia do jogo, "lá estavam os representantes do esporte local, autoridades e a banda de música". Os paulistas iniciam a partida, "agindo com impetuosidade". Depois de alguns minutos, "se esforçando de uma maneira assombrosa", marcam o primeiro gol da disputa. Procurando mostrar eficiência, a equipe local, do Anápolis Sport Club, "se desdobra em esforços", até que consegue o empate. "A animação é geral e o jogo toma aspectos nunca vistos em nossa praça de esportes [...] Enfim, Anápolis assistiu um belo jogo e deu provas, não só do seu valor esportivo, como também de um boa educação". ${ }^{56}$

Jogos intermunicipais e interestaduais, em suma, foram importantes para o desenvolvimento do esporte em Goiás. Embora times de futebol já estivessem estabelecidos em várias cidades, o pequeno número de jogadores era ainda obstáculo para uma disseminação mais regular e sistemática. Basicamente, faltavam às vezes adversários para a realização das pugnas, conforme registrou João Alves Filho: "nem sempre essas cidades mantinham em atividade as suas equipes. Em muitas oportunidades, quando uma estava bem a outra estava inativa". ${ }^{57}$

Um dos principais facilitadores da superação desse estado de coisas foram as estradas de rodagem, cujo intenso e progressivo processo de construção iniciou-se a partir de 1917. Com subsídios do governo, particulares construíam e exploravam economicamente as estradas, cuja extensão total em 1920 já era de 1.200 quilômetros. ${ }^{58}$ Em 1921, havia já mais de 28 estradas ligando vários pontos do vasto estado. Anápolis, Curralinho, Roncador, Trindade, Goiabeira, Morrinhos, Caldas Novas, Goiás, Capelinha, Pirenópolis, Santa Rita do Paranaíba, Pouso Alto, Cachoeira, São José Mossamedes, Bela Vista, Ipameri, Cristalina, São José do Duro, Barreiras, Rio Verde, Jataí, Mineiros, Barro Preto, Barro Branco, Pilar eram algumas das cidades atendidas por estradas nessa época..$^{59}$ No fim de 1927 já seriam mais de 3.500 quilômetros de estradas. ${ }^{60}$

As inúmeras estradas de rodagem construídas no início da década de 20, formando uma verdadeira rede rodoviária que convergia para o terminal ferroviário do Roncador e outros pontos da linha, ligando várias cidades

\footnotetext{
${ }^{56}$ Paulistas x Goianos. Annapolis, Annapolis, 20 set. 1936, n. 45, p. 3.

${ }^{57}$ ALVES FILHO, op. cit., p. 46.

${ }^{58}$ BORGES, op. cit., p. 108.

${ }^{59} \mathrm{Cf}$. NOGUEIRA, op. cit.

${ }^{60}$ SILVA, op. cit., p. 31.
} 
aos trilhos, fizeram com que o raio de expansão do processo modernizante extrapolasse os limites da região da Estrada de Ferro. ${ }^{61}$

Articulado a este processo, iniciou-se, nessa época, a criação de empresas de transportes de cargas e passageiros, realizados por carros ou caminhões, como era o caso da Auto-Viação Goyana, da Empresa Pio da Silva ou da Auto Viação Corumbahyense, entre outras. Algumas dessas empresas ofereciam o serviço entre duas ou mais cidades até três vezes por semana, expandindo, assim, as possibilidades de circulação de pessoas e mercadorias, com amplas consequências para a vida social de Goiás, incluindo as possibilidades de práticas esportivas. "Aos poucos", conforme avaliara Joaquim Rosa, "o automóvel foi se integrando na paisagem e na vida das comunas goianas, transportando gente, carregando mercadorias, despertando ambições, trazendo esperanças de progresso, insopitados anseios de renovação, provocando sonhos nunca sonhados". ${ }^{62}$

Quando em dezembro de 1925 uma equipe de Anápolis viajou até Goiás para enfrentar um time daquela cidade, um caminhão foi o veículo que serviu ao transporte dos jogadores. ${ }^{63}$ Alguns anos depois, partidas desse tipo, intermunicipais, mobilizariam já mais de 70 pessoas, viajando em diferentes automóveis, como ocorreu na partida entre o Burity Futebol Clube e a equipe de Santa Rita do Paranaína, em novembro de $1935 .{ }^{64}$ Em certos casos, por ocasião de partidas muito aguardadas, como uma entre a Associação Athletica União Goyana e a União Esportiva Ipamerina, dois velhos e intrépidos rivais, "muito antes do seu início já automóveis e caminhões superlotados, subiam para o campo [do Areião, na cidade de Goiás], levantando uma nuvem densa de poeira" ${ }^{65}$

Todavia, não se deve depreender de tudo isso que uma transformação irrestrita estivesse em curso em Goiás. Para todos os efeitos práticos, Goiás tivera uma formação fundamentalmente rural até anos avançados do século XX. Segundo dados do censo demográfico e econômico de 1940, a maioria da população economicamente ativa da região (38\%) empregava-se em trabalhos diretamente ligados à agricultura e à pecuária. Mesmo considerando-se ocupações mais modernas, simbolicamente ligadas ao ambiente urbano das

\footnotetext{
${ }^{61}$ BORGES, op. cit., p. 108.

${ }^{62}$ ROSA, op. cit., p. 56.

${ }^{63}$ ALVES FILHO, op. cit., p. 51

${ }^{64}$ Futebol. Burity, Burity-Alegre, 24 nov. 1935, n. 39, p. 1.

${ }^{65}$ A União Goiana versus União Ipamerina. Correio Official, Goyaz, 26 jul. 1934, n. 2804, p. 4.
} 
cidades, como o "comércio de mercadorias" ou "transporte e comunicação", que respondiam por apenas $4 \%$ das formas de ocupação, encontrava-se, na prática, trabalhadores empregados no "transporte à tração animal" ou na "venda de gêneros alimentícios e produtos agropecuários". ${ }^{66}$

Sociedades de fronteira, como classificou José de Souza Martins, são lugares da alteridade, isto é, dos desencontros das temporalidades históricas, do convívio de grupos situados diversamente no tempo. De um lado, a inovação representada pela contratualidade das relações sociais, pelas instituições políticas e jurídicas propriamente modernas, pela economia de mercado, pela agricultura em larga escala, pelo empresário capitalista que constrói cidades e modernas vias de comunicação. De outro lado, contudo, uma mentalidade menos ligada ao ambiente urbano e mais ao trabalho no campo, regulado pelos ritmos da natureza, numa economia rústica, com relações contratuais nem sempre reguladas pelo pagamento de salários em dinheiro. Tudo isso também fazia parte daquela realidade. São modos de pensamento e de conduta social contraditórios, mas que coexistem no mesmo tempo histórico. ${ }^{67}$

Em Goiás, particularmente, no momento em que se intensificava a construção de estradas para veículos automotivos, incentivava-se também a construção de estradas para carros de bois, até mesmo para evitar, ou pelo menos minimizar, o estrago que as pesadas rodas dos "cometas" provocavam nas recém-inauguradas estradas do Estado. ${ }^{68} \mathrm{Em} 1931$, quando se contabilizava aproximadamente 133 automóveis em Goiás, símbolos inequívocos de progresso e modernidade, sabia-se também da existência de pelo menos 150 carros de boi em cada um dos municípios goianos. ${ }^{69}$ De outra forma, enquanto se registrava uma "febre de progresso" nas cidades do sul do estado, conforme registrou o jornal Voz do Povo, ${ }^{70}$ cidades como Morrinhos, Formosa ou mesmo Goiás, capital política do estado, poderiam ser representadas ainda como cidades de poeira e lama, "imutáveis por muito tempo", "sem atrativos de ordem urbanística" e com suas características estradas esburacadas, exercendo a dupla função de logradouro público e pasto para animais, com seus quarteirões inteiros sem casas, iluminadas à vela e construídas no

\footnotetext{
${ }^{66}$ BRASIL. Recenseamento geral do Brasil. vol. XXI. Rio de Janeiro: Serviço Gráfico do Instituto Brasileiro de Geografia e Estatística, 1952, p. 94.

${ }^{67}$ MARTINS, op. cit.

${ }^{68}$ Nova estrada para carro de bois. Correio Official, Goyaz, 04 set. 1920, n. 287, p. 11.

${ }^{69}$ NOGUEIRA, op. cit., p. 33.

${ }^{70}$ Voz do Povo, Goyaz, 02 de setembro de 1927, apud. SILVA, op. cit., p. 116.
} 
velho estilo, com "muros de adobe de barro, revestidos com reboque aqui e ali, feito de areia misturada com bosta fresca de vaca". ${ }^{71}$

Desse modo, justapondo tradição e modernidade, jogadores do Jaraguá Esporte Clube, já adeptos de modernos costumes como os sports, viajavam até Pirenópolis, em meados de 1926, para uma partida de football durante a tradicional festa do divino. Para o transporte, parte dos jogadores valia-se de automóveis, enquanto outros, à moda antiga, montavam seus cavalos. Depois de um dia inteiro de viagem, os jogadores eram geralmente recebidos por "muita gente na entrada da cidade", com rojões, foguetes e ao som da banda de música. Segundo depoimento de Natal Soares de Castro, um dos craques do time de Jaraguá na ocasião:

$\mathrm{Na}$ época em que recebemos o convite para irmos a Pirenópolis [por volta de junho de 1926], Jaraguá possuía apenas três automóveis, todos da marca Ford. Os três não davam para transportar o time e mais um ou dois dirigentes. Os três automóveis seguiram no sábado pela manhã. Eu e o Lauro Gonçalves fomos à cavalo. Chegamos no sábado já dentro da noite. ${ }^{72}$

A dimensão urbana da vida em Goiás nesse período deve ser bastante relativizada, portanto, em que pese, simultaneamente, as inegáveis e profundas transformações que se processavam. Nesse sentido, núcleos urbanos em Goiás se caracterizavam por um alto padrão de rusticidade, uma "sociedade marcadamente rural, com alguns poucos núcleos urbanos em meio rural", conforme definiu Ana Lúcia da Silva. ${ }^{73}$ Foi neste contexto ambivalente, perpassado a um só tempo por traços de tradicionalismo e inovações modernizadoras que os esportes se desenvolveram em Goiás. Assim, ao mesmo tempo em que se testemunhava um ambiente esportivamente vibrante, permeados já por pugnas renhidíssimas, arrebatando grande assistência, viam-se também "duvidas que ainda anuvia[va]m os horizontes goianos no tocante ao cultivo do esporte em geral, e do futebol em particular". ${ }^{74}$

\section{O esporte e a retórica do progresso}

Além das transformações nas condições materiais do cotidiano em Goiás, uma nova mentalidade, de certo modo mais progressista, mostrar-se-ia fundamental para o desenvolvimento do futebol na região. Em verdade,

\footnotetext{
${ }^{71}$ ROSA, op. cit. passim.

${ }^{72}$ ALVES FILHO, op. cit., p. 43.

${ }^{73}$ SILVA, op. cit., p. 61.

${ }^{74}$ EVERS. Futebol em Uberlândia: União Goiana x Uberabinha. Correio Official, Goyaz, 12 jul. 1934, n. 2794, p. 1 e 8 .
} 
a vinculação simbólica entre uma espécie de retórica do progresso e o esporte foi um dos elementos a tornar possível, ao menos do ponto de vista de certos setores das elites de Goiás, esforços mais sistemáticos para difusão dessas práticas. Em 1927, correspondente do jornal Voz do Povo enviou através de telegrama notícias sobre o campeonato brasileiro de futebol realizado no Rio de Janeiro, com representantes de vários estados, menos Goiás, que não esteve presente. Segundo as palavras do correspondente, claramente ressentidas, "até os piauienses vieram exibir seu valor desportivo [...] como nos seria gratos aos goianos aqui residentes saudosos de Goiás, podermos aplaudir, no estádio, os nossos conterrâneos!" ${ }^{75}$

Nessa época, intelectuais, artistas, políticos e outros membros da elite goiana desenvolveram grande preocupação em inverter o modo de representação da região diante do resto do Brasil. Em 1917, como resultado dessas preocupações, foi lançada, no Rio de Janeiro, a revista A informação goyana, "revista mensal, illustrada e informativa das possibilidades econômicas do Brasil Central". A iniciativa, segundo o editorial do seu primeiro número, justificava-se "pela própria necessidade que havia de um órgão informativo e de propaganda das incomparáveis riquezas nativas do hinterland brasileiro - essa vastíssima região quase desconhecida sob todos os seus aspectos". ${ }^{76}$ No mesmo sentido, em 1927, um grupo de goianos radicados no Rio de Janeiro se articulou para a criação do que eles chamaram "Centro Goyano": um espaço social destinado a congregar os conterrâneos residentes na capital federal, além de visar, "especialmente", diziam as notícias, "a propaganda de Goyaz". ${ }^{77}$ Assim, comprometidos que estavam com a edificação de outra representação para a região, desvinculando-a da imagem do atraso e do subdesenvolvimento, a ausência de uma equipe goiana no campeonato brasileiro de futebol passava a ser tomada como expressão sintomática de algo que precisava ser radical e rapidamente transformado.

Em parte como resultado dessas inquietações, no início de 1930, pequeno grupo de entusiastas do esporte começava a anunciar intenções de criar em Goiás uma associação ou liga esportiva. Argumentava-se que vários clubes de Goiás tinham seu desenvolvimento dificultado "pela falta de uma

\footnotetext{
${ }^{75}$ Do Rio. Voz do Povo, Goyaz, 28 out. 1927, n. 19, p. 1.

${ }^{76}$ A Informação Goyana. A Informação Goyana, Rio de Janeiro, 15 ago. 1917, vol. I, n. 1, p. 1.

${ }^{77}$ Centro Goyano. Voz do Povo, Goyaz, 16 set. 1927, n. 13, p. 3. Iniciativas análogas já haviam se registrado antes disso. Logo após a proclamação da República, um outro "Centro Goyano", com propósito e organização muito semelhante, fora criado na capital federal. Cf. o jornal Goyaz, Goyaz, 24 out. 1890, n. 266, p. 3.
} 
entidade superior que os dirija". ${ }^{78}$ Outra preocupação era a criação de uma equipe de futebol em condições de representar Goiás nos campeonatos nacionais, salientando-se "a grande vantagem de se tornar a mocidade goyana conhecida em todo o Brasil". Conforme se dizia, "num Estado como o nosso, central, e que com cidades já importantes em seu hinterland, haverá - e disso estamos certos - elementos capazes de nos representar galhardamente no Campeonato Brasileiro de Futebol" (cuja primeira realização aconteceu em 1922)..$^{79}$

Nesses termos, a ideia de uma liga ou associação esportiva logo começou a ser percebida como "uma grande necessidade que se fazia sentir", uma "útil entidade", "uma iniciativa feliz", "simpática e proveitosa missão"; algo, enfim, que viria a "contribuir de forma edificante para o progresso do estado". A recorrente comparação com a situação de outras regiões do Brasil no que diz respeito aos esportes exprimia a clara preocupação das elites goianas em se fazer representar diante da nação, também através do esporte. Nesse sentido, a possibilidade de ter uma equipe goiana no campeonato nacional de futebol era uma das principais justificativas a animar os envolvidos com a criação de uma associação esportiva. Não por acaso, tais entusiastas, os sportmen goyanos seriam apresentados como representantes do espírito progressista e empreendedor do povo de Goiás. Segundo dizia-se:

Sabemos, todos o sabem, o grau de desenvolvimento dos desportos, tanto
terrestres como aquáticos, em todos os Estados do Norte do Brasil; mesmo
nos menores. Todos eles disputam, anualmente, o Campeonato Brasileiro
de Futebol, demonstrando que os seus filhos bem compreendem o valor do
desenvolvimento físico. Porque só Goyaz há de permanecer na retaguarda,
quando possui elementos magníficos que são penhor iniludível de Vitória?

A Associação Goiana de Esportes Athleticos (Agea) de fato foi criada e conseguiu deflagrar uma relativa mobilização ao redor de sua causa: o desenvolvimento dos esportes em Goiás. Comerciantes, artistas, políticos, jornalistas, poetas, escritores e populares se uniram para apoiar sua criação, bem com suas ações. Pouco tempo depois, no início de setembro, anunciou-se uma "Lista Pró-Estádio", cuja finalidade era a obtenção de recursos para construção de um estádio, a ser administrado pela recém-fundada Agea. Os prêmios a serem oferecidos ficavam expostos na vitrine da Casa Nicolau

\footnotetext{
${ }^{78}$ O esporte em Goyaz. Voz do Povo, Goyaz, 04 jul. 1930, n. 158, p. 3.

${ }^{79}$ A nova entidade esportiva. Voz do Povo, Goyaz, 25 jul. 1930, n. 161, p. 3.

${ }^{80}$ Associação Goiana de Esportes Athleticos. Voz do Povo, Goyaz, 18 jul. 1930, n. 160, p. 1.
} 
Saddi, no Largo do Palácio. Os valores arrecadados, por seu turno, deveriam ser entregues ao Sr. Sebastião da Rocha Lima, na Confeitaria Esperança, na Praça Pinheiro Machado, n. 16. Quem mais assinaturas obtivessem, escolheria um dos quatro prêmios ofertados, a saber: um relógio de ouro para bolso, um relógio pulseira de ouro, um relógio de mesa "com lindo e rico pedestal" e um "estojo caríssimo para escritório". Aos que conseguissem mais de 150 assinaturas prometiam-se ainda "lindíssimos prêmios de preços elevados". ${ }^{1}$

Organizadas pelo Comitê Feminino Pró-Estádio, as listas, vencidas, no fim, pelas senhorinhas Olinda Paiva e Ida de Artiaga ${ }^{82}$ - o que revela o envolvimento das mulheres nessa atividade -, arrecadaram mais de um milhão e duzentos mil réis, devidamente depositado no Banco Hypothecario e Agrícola do Estado de Minas Gerais, em sua agência da Cidade de Goiás. ${ }^{83}$ Em fins de setembro de 1930, já com os recursos provenientes da Lista Pró-Estádio disponíveis aos dirigentes da Agea, organizou-se um "grande mutirão", que previa a participação de "todos os esportistas da capital". Esta iniciativa parece ter sido particularmente eficiente na mobilização dos "bons goyanos", dispostos em trabalhar pelo "progresso de Goyaz". ${ }^{84}$ Antes, porém, operários contratados especificamente para esse fim, realizaram os "trabalhos braçais", especialmente o de roçar toda a área que serviria ao novo estádio, conforme recomendado pelo engenheiro responsável pelas obras. Aos estudantes e esportistas, assim, não caberia "o trabalho de foice, encontrando já a grande praça descampada, sendo apenas preciso igualar o terreno".

Rapazes que possuíam automóveis, como Péricles Fleury, Calígula Macedo, Claudio Cunha e outros, puseram as suas "máquinas" à disposição do Comitê Feminino - efetivamente responsável pela organização do mutirão -, caso as lindas senhorinhas quisessem "levar farnéis ao operariado que se empenhará nas enxadas e nas pás pelo progresso de Goyaz". o Comitê Feminino obteve ainda empréstimo por um dia de todas as ferramentas da Secretaria das Obras do Estado. "Esportistas, civis, militares, estudantes, todos, enfim, tem trazido o seu apoio em prol da construção do estádio". ${ }^{85}$

Apesar da ativa participação dos "bons goyanos", e também das boas goyanas, os louros desta realização caberiam em larga medida a um paulista. Genaro Rodrigues, funcionário dos Correios transferido para a capital de

81 As listas do estádio. Voz do Povo, Goyaz, 05 set. 1930, n. 167, p. 3.

82 A entrega dos prêmios. Voz do Povo, Goyaz, 19 set. 1930, n. 169, p. 2.

83 Pró-Estádio. Voz do Povo, Goyaz, 19 set. 1930, n. 169, p. 3.

84 A pedra fundamental do estádio. Voz do povo, Goyaz, 19 set. 1930, n. 169, p. 2.

85 O muxirão do estádio. Voz do Povo, Goyaz, 26 set. 1930, n. 170, p. 2. 
Goiás em fins de 1929, seria, tanto em São Paulo quanto em Goiás, apontado como o principal responsável pela criação da primeira liga esportiva goiana. Segundo se dizia em São Paulo:

Graças a um esportista de S. Paulo, Goyaz vai reunir os clubes esparsos pela capital e cidades do seu vasto interior em uma Associação e disputar regularmente os jogos e, logo que possível, no próximo ano talvez, concorrer ao certame brasileiro, estando desde já a novel Associação tratando de filiar-se a entidade do qual o Sr. Renato Pacheco, é presidente [Confederação Brasileira de Desportos]. Esse grande empreendimento, embora tardio, os goyanos o ficaram devendo, em grande parte, ao nosso distinto colega e prezado colaborador, NAGE (Genaro Rodrigues) que, como já tivemos oportunidade de publicar, se encontra há tempos na capital goyana, em missão nos correios gerais de Goyaz. ${ }^{86}$

Edificando uma imagem caricatural de Goiás, “o colossal Estado do Planalto Brasileiro", que "até bem pouco quase não cultivava o mais popular esporte", onde os clubes seriam raros e os demais esportes conhecidos por poucas pessoas, mesmo assim apenas "teoricamente", jornais de São Paulo reforçavam, de forma talvez exagerada, o papel de Genaro Rodrigues na criação da Agea.$^{87}$ Conhecido nas rodas esportivas de São Paulo, onde atuava como diretor de clubes de esporte, jurado de luta-livre, árbitro de futebol ou representante da Associação Paulista de Esportes Athleticos (Apea) ${ }^{88}$, Genaro Rodrigues era representado como alguém de "espírito irrequieto e empreendedor", legítimo herdeiro da velha tradição bandeirante. Foi ele, afinal, quem notou, "logo ao chegar no longínquo Estado, a falta que fazia para o desenvolvimento do futebol naquelas paragens, de um órgão que centralizasse todas as energias, as quais, reunidas, irão dar benéficos resultados ao esporte do pé-bola". Nesse espírito, Genaro Rodrigues "não descansou enquanto não viu organizada a Associação Goyana de Esportes Athleticos”.

Em Goiás, igualmente, pouco menos de um ano após a fundação da entidade, jornais locais se apressavam em dizer que o futebol se desenvolvia satisfatoriamente, "depois que se fundou, graças aos esforços do grande esportista Genaro Rodrigues, a Associação Goyana de Esportes Athleticos”. ${ }^{89}$ Alguns

\footnotetext{
${ }^{86}$ O futebol em Goyaz. Folha da Manhã, São Paulo, 19 jul. 1930, n. 1868, p. 11.

${ }^{87}$ Idem.

${ }^{88}$ Para esses acontecimentos, cf. Capoeira contra jiu-jitsu. Folha da Manhã, São Paulo, 12 jan. 1929, p. 10; Campeonato do interior. Folha da Manhã. São Paulo, 19 jan. 1929, n. 1342, p. 9; Estrella de Ouro tem nova directoria. Folha da Manhã, São Paulo, 01 jan. 1932, n. 2260, p. 12; APEA se reuniu hontem, em Assembleia. Folha da Manhã, São Paulo, 29 ago. 1931, n. 2154, p. 11.
}

${ }^{89}$ Futebol. Correio Official, Goyaz, 19 mar. 1931, n. 1870, p. 6-7. O grifo é meu. 
anos depois, consolidando, retrospectivamente, a imagem quase mítica ao redor do esportista paulista, cronistas goianos, já implicados em disputas de poder pelo controle institucional do esporte em Goiás, asseverariam que fora ele, Genaro Rodrigues, na época em que "os esportes eram praticados [em Goiás] longe de como se praticam nos adiantados centros", quem "os corrigiu e emprestou-lhes cunho moderno e evolutivo". ${ }^{90}$

De fato, Genaro Rodrigues parece ter oferecido participação importante no desenvolvimento do esporte em Goiás, ou melhor, no processo de criação da Agea. Fora ele quem provavelmente animara a ideia, sugerindo, inclusive, adoção do mesmo modelo adotado pela Associação Paulista, com a qual ele próprio já estava familiarizado. Não por acaso, até o nome da Associação Goiana seguia o modelo adotado em São Paulo. Foi ele também quem se ocupou pessoalmente em requisitar ao Dr. Elpídio de Paiva Azevedo, presidente daquela entidade, seus estatutos, códigos e regulamentos, que foram adotados em larga medida em Goiás..$^{91}$

Nada disso, contudo, deve minimizar o envolvimento e a contribuição dos próprios goianos. A primeira diretoria da entidade logo mobilizou importantes figuras da vida social da capital, como Cesar de Alencastro Veiga, José de Alvarenga Peixoto, Sebastião da Rocha Lima, Joaquim Ramos Jubé Junior, Claudio Cunha e Jacques Saddi, entre outros. Muitos deles, inclusive, já contavam com um histórico de participação e apoio a práticas esportivas em Goiás desde antes, quer como árbitros, jogadores ou apenas incentivadores. Em verdade, foi este o grupo, ao lado de mulheres como Maria Carlota Guedes, Maria Augusta da Rocha, Floracy Artiaga, entre outras, quem efetivamente viabilizou boa parte das condições necessárias para criação de uma associação esportiva em Goiás, para não mencionar os inúmeros anônimos que aderiram e apoiaram de diferentes maneiras a iniciativa: comprando listas, ocupando-se da construção do estádio ou simplesmente assistindo as partidas realizadas na capital. ${ }^{92} \mathrm{~A}$ ideia de criar uma Associação de Esportes em Goiás, afinal, encontrou "insuperável apoio em todas as classes sociais desta capital", conforme noticiava a imprensa goiana já em meados de julho de $1930 .{ }^{93}$

\footnotetext{
${ }^{90}$ H. B. A apatia em que vive a Agea. Correio Official, Goyaz, 18 fev. 1934, n. 2679, p. 3.

${ }^{91}$ O futebol em Goyaz. Folha da Manhã, São Paulo, 19 jul. 1930, n. 1868, p. 11.

${ }^{92}$ Para uma lista completa das integrantes do Comitê Feminino da Agea, ver Associação Goyana de Esportes Athleticos. Voz do Povo, Goyaz, 29 ago. 1930, n. 166, p. 2.
}

${ }_{93}$ Associação Goyana de Esportes Athleticos. Voz do Povo, Goyaz, 18 jul. 1930, n. 160, p. 1. 
A julgar pelos resultados imediatos de tal mobilização, parece mesmo ter sido considerável o apoio dos goianos a tal iniciativa. Afora as subscrições decorrentes da Lista Pró-Estádio e o mutirão para a sua construção, foi realizado ainda um baile na Escola de Farmácia e a exibição de um filme no cinema da cidade, visando levantamento de mais fundos para a associação. ${ }^{94}$ Em 1934, estimava-se que o valor total arrecadado com tais atividades fora da ordem de três milhões de contos de réis. ${ }^{95}$ Além disso, antes mesmo da criação da entidade, como vimos, alguns setores da elite política e social de Goiás já manifestavam preocupações quanto a importância de organizar-se mais e melhor os esportes ali, lamentando-se da ausência de representantes goianos nos campeonatos nacionais de futebol. Além disso, acontecimentos esportivos já estavam em curso de maneira mais ou menos bem delineadas, ao menos desde princípios da década de 1920.

É simplesmente equivocado, portanto, a avaliação publicada na imprensa paulista de que não havia clubes, nem campeonatos em Goiás antes da criação da Agea. É certo que o período posterior a 1930 testemunhou uma considerável intensificação das atividades esportivas em Goiás, sobretudo do futebol. Mas esse processo não necessariamente está vinculado à criação da Associação Goiana, que teve papel reduzido nesse sentido. Na prática, apenas três clubes da capital filiaram-se à Agea, ${ }^{96}$ que tinha, em última instância, um caráter bastante seletivo; excludente mesmo. Sua assembleia, de acordo com os estatutos, era constituída por representantes dos clubes de todas as divisões que a própria associação instituiu (Divisão Principal, Primeira Divisão, Segunda Divisão, Divisão Municipal e Divisão do Interior), por representantes dos dois conselhos de sua diretoria (o fiscal e o consultivo), além dos membros das suas três comissões permanentes (de justiça, de sindicância e de esportes). Os membros dessas últimas três comissões seriam nomeados pelo presidente da Agea, entre os sócios dos clubes filiados. Mais que isso, porém, era necessário ter mais de 21 anos, não ter ou estar sofrendo "penalidades por atos deprimentes", bem como "possuir instrução e capacidade que os recomendem para o cargo". ${ }^{97}$

A comissão de sindicância, por sua vez, a quem cabia "julgar os pedidos de registro de jogadores”, não poderia, conforme prescrito nos estatutos

\footnotetext{
${ }^{94}$ Associação Goyana de Esportes Athleticos, balanço da diretoria. Correio Official, Goyaz, 19 dez. 1930 , n. 1796, p. 3.

${ }^{95}$ H. B. A apatia em que vive a Agea. Correio Official, Goyaz, 18 fev. 1934, n. 2679, p. 3.

${ }^{96}$ Futebol. Correio Official, Goyaz, 19 mar. 1931, n. 1870, p. 6-7.

${ }^{97}$ Associação Goyana de Esportes Athleticos, estatutos. Correio Official, Goyaz, 02 ago. 1930, n. 1727, p. 10.
} 
da entidade, mandar registrar os analfabetos, os que não tivessem boa educação e profissão honesta, os que não tivessem boa reputação, bem como os profissionais do esporte, isto é, "os que recebem de seu clube remuneração de qualquer espécie". ${ }^{98}$ Numa sociedade em que dados oficiais de 1940 registrariam ainda $43 \%$ da população analfabeta ${ }^{99}$, apenas esse critério, em si mesmo, para não mencionar os demais, representava claramente um esforço, consciente ou não, em dificultar, se não impedir o acesso de camadas populares ao controle institucional dos esportes, reproduzindo, de certo modo, as disputas políticas que marcaram o desenvolvimento do esporte em outras regiões do Brasil. ${ }^{100}$

Mas não era apenas a jogadores, individualmente, que se impunham restrições. A adesão de clubes também precisava atender a um conjunto considerável de exigências. Para se filiar a Agea, um clube deveria ter sedes social e esportiva, pagar taxas de joias e anuidades, além de ter estatutos, vale dizer, estar constituído como uma entidade jurídica formal, o que custava, aproximadamente, 300 mil contos de réis, de acordo com o valor pago pela própria Agea no seu processo de formalização burocrática. As joias custavam 50 mil conto de réis para a divisão principal e para a primeira divisão, e 30 mil contos de réis para as demais. A isso, somavam-se outros 30 mil contos de réis de anuidade, igual para todas as divisões, bem como outros dois mil contos de réis por cada jogador inscrito nos clubes da divisão principal. $\mathrm{Da}$ mesma forma, para mudar de nome ou de cores, o time, além de depender de aprovação da diretoria da Agea, deveria pagar uma taxa correspondente ao dobro da joia de sua divisão, além de nova taxa de inscrição de todos os seus jogadores. ${ }^{101}$

Assim, um clube com 24 jogadores que pretendesse fazer parte da divisão principal da Agea deveria desembolsar, de início, apenas com taxas e joias destinadas à própria Agea, 128 mil contos de reis, isto se já estivesse

\footnotetext{
${ }^{98}$ Idem. p. 13.

${ }^{99}$ Brasil, op. cit., p. 16.

${ }^{100}$ Para uma análise das disputas ao redor da atribuição de sentido social ao jogo no contexto do Rio de Janeiro, bem como pelo controle político das instituições que regulamentavam o jogo, ver PEREIRA, op.cit. Segundo o autor, já em princípios do século XX, muitos sportmen do Rio de Janeiro viam na popularização do foot-ball um fator de degradação do sentido mais profundo que eles mesmos desejavam atribuir ao jogo. Como resposta, deflagraram-se esforços para a proibição do acesso de "rapazes que não eram dignos", tais como "pessoas de cor", jogadores profissionais ou mesmo os que já tivessem se empregado em qualquer tipo de trabalho braçal. Segundo Pereira, tais iniciativas representavam um esforço das elites locais em tentar tomar para si a primazia do jogo, definindo as regras e os grupos que iriam praticá-lo.

${ }^{101}$ Associação Goyana de Esportes Athleticos, estatutos. Correio Official, Goyaz, 02 ago. 1930, n. 1727, p. 10.
} 
devidamente registrado em cartórios competentes, do contrário, o valor final subiria para 428 mil contos de réis. Não obstante, os clubes interessados deveriam ainda ter posse de um campo de futebol, dado que o artigo 54 dos estatutos da Agea dizia explicitamente que "não podem ser admitidos à divisão principal, nem mesmo ter acesso, os que não possuírem, por compra, sessão ou qualquer outro título, um campo com dimensões legais e outros requisitos para serem nele disputado jogos de campeonato". Tais exigências poderiam representar dificuldades razoáveis. Em 1931, 428 mil contos de réis seriam suficientes para comprar 214 ingressos populares para um espetáculo do Circo Urano - "grande plêiade de artistas" que se apresentou naquele ano na capital goiana; mais que o dobro do valor pago pelo Catalão Foot-ball Club na compra do terreno para o seu estádio em $1922 .{ }^{102}$

Não por acaso, menos de um ano após sua fundação, a entidade já parecia se ressentir da baixa adesão dos clubes, sobretudo os do interior. Artigo anônimo publicado no Correio Official, lamentava as dificuldades da Agea finalmente conseguir um dos seus principais propósitos: filiar-se à Confederação Brasileira de Desportos e participar dos campeonatos interestaduais promovidos por aquela entidade, pois, para isso, era necessário cumprir "algumas exigências", entre as quais, conforme esclarecia o anônimo missivista, "a de possuir um certo número de clubes filiados". Ainda segundo o mesmo informante:

Sabido é que o interior do nosso Estado dispõe de grande numero de
esport'smans [sic]-faltando, somente, um pouquinho da boa vontade esfor-
ço para organizarem os clubes com as respectivas Diretorias e tornarem-se
pessoa jurídica (registrados no cartório competente), afim de, sem dificul-
dades, se filiarem á Agea, entidade máxima que dirige o esporte em nosso
Estado. $^{103}$

Em 1932 já apareciam críticas a falta de "encontros oficiais de futebol", ao "péssimo estado dos campos", ao "desânimo individual em nossos sportmen", ao "marasmo esportivo", enfim. Tudo isso parecia estar arrefecendo o entusiasmo dos próprios apreciadores do esporte, segundo avaliava-se. Nesse sentido, conclamavam-se os entusiastas do esporte à ação: "Façamos a arregimentação dos melhores elementos do Estado e filiemolos à Agea. Organizemos também o campeonato da cidade, a fim de que,

\footnotetext{
${ }_{102}$ Para o valor dos ingressos nos espetáculos do Circo Urano, ver Circo Urano. Correio Official, Goyaz, 09 nov. 1931, n. 2050, p. 4. Para o valor do terreno pago pelo Catalão Foot-ball Club, ver RAMOS, op. cit.

${ }^{103}$ Futebol. Correio Official, Goyaz, 19 mar. 1931, n. 1870, p. 6-7.
} 
amanhã, com bons selecionados, possamos transpor os morros que sitiam nossa Capital, à procura de melhores contendores". ${ }^{104}$

Tais palavras de ordem não parecem ter surtido efeito, pois em princípios de 1934, o cronista H. B. lamentava a "existência efêmera" da Agea, vítima de uma "catalepsia" em sua existência, segundo ele, "devido a falta não só de recursos, como também de animo e uma certa vontade da diretoria". ${ }^{105}$ Para H. B., eram urgentes esforços para superar a apatia da agremiação, precisando, para isso, apenas de uma "existência real". ${ }^{106}$

Talvez em resposta às implacáveis críticas de H. B, uma mobilização para o reerguimento da Agea foi deflagrada entre alguns sportmen da capital goiana. Nessa época, reuniões foram realizadas, a fim de tentar reorganizarse uma diretoria provisória. Ao que parece, foram infrutíferas também tais tentativas, pois nos meses seguintes, não mais se falaria na Agea, apesar da intensa mobilização esportiva que passou a afetar a capital goiana daí em diante, inteiramente à revelia de qualquer iniciativa ligada a uma entidade centralizadora. Os embates futebolísticos que mobilizaram grande número de torcedores a partir de 1930 e 1931 eram resultado de acordos firmados diretamente entre os próprios times, geralmente através de telegramas, sem apoio ou intermediação de nenhuma liga ou associação esportiva.

Num contexto de progressivo crescimento das atividades esportivas em Goiás, antes e depois do período de funcionamento da Agea, os motivos para o fracasso da iniciativa parecem estar menos na eventual acefalia provocada pelo regresso de Genaro Rodrigues a São Paulo, do que na própria maneira como se constituiu tal entidade. Não foi a saída de um importante sportman paulista dos quadros dirigentes da recém-criada associação esportiva o motivo de seu fracasso. Ao contrário, foi o fato mesmo de ter adotado um modelo de organização importado de São Paulo, reproduzindo, assim, de maneira tanto quanto anacrônica os embates políticos daquele contexto, o principal motivo para esse desfecho. À época da criação da Agea, o desenvolvimento esportivo em Goiás ainda não parecia conhecer um processo de popularização que justificasse a adoção de medidas visando obstruir o acesso de grupos populares nas cadeias decisórias das instituições oficiais do esporte, como acontecia em São Paulo e no Rio de Janeiro desde os fins da primeira década do século XX, ainda que fosse este o desejo. Na capital

\footnotetext{
${ }^{104}$ Pelo esporte. Voz do Povo, Goyaz, 14 fev. 1932, n. 223, p. 4.

${ }^{105}$ H. B. A apatia em que vive a Agea. Correio Official, Goyaz, 18 fev. 1934, n. 2679, p. 3.

${ }^{106}$ H. B. Sobre a Agea. Correio Official, Goyaz, 04 mar. 1934, n. 2690, p. 2.
} 
goiana, apenas em 1935, quando a Agea já não mais existia, tem-se notícias da criação de um clube operário. ${ }^{107}$

Em outras palavras, foi o próprio modo de estruturação da Agea o que parece ter funcionado como principal obstáculo para o seu desenvolvimento. As exigências para a filiação provavelmente desestimulava a maioria dos times que existiam e atuavam por várias cidades do interior de Goiás, aparentemente, de maneira informal, isto é, sem estatutos ou quaisquer outras formas de burocratização institucional. Em segundo lugar, os estatutos da Agea prescreviam tal monopólio sobre os eventuais benefícios decorrentes do desenvolvimento esportivo em Goiás, que poucos times, mesmo que quisessem, teriam, de fato, interesse em vincular-se à associação. De acordo com os estatutos, todos os jogos da divisão principal seriam jogados na capital; a realização de jogos amistosos dependeria de licença concedida pelo presidente da Agea; além disso, 1/3 da renda de todos os jogos seriam destinados à associação. ${ }^{108}$

\section{Considerações finais}

Não seria razoável supor o desenvolvimento do futebol em Goiás como o resultado da ação de um único indivíduo, isolado, mas com poderes de organizar uma estrutura organizacional dentro de um curto espaço de tempo, restrito há alguns poucos meses - sete, para sermos mais precisos, a contar da chegada de Genaro Rodrigues à Goiás até a inauguração da Agea. Longe disso, havia já toda uma ambiência favorável à deflagração desse processo, cujo desenvolvido datava de alguns anos. Nesse sentido, o desenvolvimento histórico do futebol em Goiás diz respeito a um longo processo social, onde uma cadeia interdependente de fatores, incluindo uma ampla rede de sujeitos e acúmulos de experiências coletivas se apresentam como os principais vetores explicativos de tal dinâmica.

\footnotetext{
${ }^{107}$ União Operária Sport Club. Correio Official, Goyaz, 19 mai. 1935, n. 3012, p. 4. Antes disso, em meados de 1920, há notícias, na capital, de um time de "operários" defrontando-se contra um time de sargentos, em jogo "sem animação", cujos eventuais influências posteriores é difícil avaliar (c.f. Foot-ball. Correio Official, Goyaz, 06 out. 1925, n. 1076, p. 3). O clube propriamente dito, União Operária Sport Club, provavelmente articulava-se com ações como a criação da "Sociedade Santa Luzia Classe Operária", criada em 1930. Entre 1920 e 1940, Goiás testemunhou "significativo aumento de estabelecimentos industriais". De acordo com os dados censitários de 1920, Goiás contava, naquele ano, 16 indústrias e 244 operários. Em 1940, esses números já seriam de 260 indústrias e 1.487 operários, representando, portanto, aumento de mais de $1500 \%$ com relação ao número de indústrias, e mais de $600 \%$ com relação ao número de operários (SILVA, op. cit., p. 46 e 157, respectivamente).

${ }^{108}$ Associação Goyana de Esportes Athleticos, estatutos. Correio Official, Goyaz, 02 ago. 1930, n. 1727, p. 10.
} 
De certo modo, a edificação de uma memória regional em que os principais protagonistas da história vêm de outras partes do Brasil, sobretudo de São Paulo, corresponde a pelo menos duas estruturas recorrentes nas narrativas históricas de Goiás. De um lado, o bandeirantismo, que prescreve a imagem dos "construtores épicos do Brasil", "os heróis paulistas"; 109 de outro, a "míngua de passado", de que se ressentem regiões periféricas, oprimidas pelo peso das macro narrativas da nação, resultado de um conjunto mais ou menos arbitrário de reduções e generalizações, onde práticas e imaginários de grupos e regiões localizadas no centro do poder político e econômico, apresentar-se-ão como representações válidas para toda a nação.

A história de Goiás é sobremaneira marcada por esta estrutura narrativa, que se submete a mecanismos de legitimação histórica subsumidos no par província-nação, sertão-litoral. Eliane Pereira, referindo-se especificamente ao caso goiano, chamou a este tropos de "complexo de decadência"; uma história cindida pelo dilema de "conhecer-se e ser reconhecido, integrar-se, participar, ser aceito, fazer-se importante para os destinos da nação", como disse, no mesmo sentido, Rubia-Mar Nunes Pinto. ${ }^{110}$ Assim, da mesma forma que "recalques terceiro-mundistas" têm favorecido, no plano nacional, o mito ao redor de figuras como Charles Miller, filho de ingleses, educado na Europa e ligado a empresas multinacionais, superdimensionando seu papel e seu lugar na memória sobre o futebol brasileiro; ${ }^{111}$ no plano regional, são estes "complexos de decadência", estes dilemas historiográficos que marcarão, de maneira análoga, a lógica que orienta a edificação da memória do futebol goiano.

Goiás conheceu um desenvolvimento esportivo relativamente precoce, especialmente se considerarmos as condições sociais que prevaleceram na primeira metade do século XX. No caso goiano, "não é a ausência de esportes o que salta os olhos, mas justamente o contrário. 0 que surpreende é mesmo a perseverança e até a obstinação com que algumas pessoas se engajaram com a prática esportiva em Goiás, apesar dos obstáculos e

\footnotetext{
${ }^{109}$ DAVIDOOF, Carlos Henrique. Bandeirantismo, verso e reverso. São Paulo: Brasiliense, 1982, p. 8.

${ }^{110}$ Respectivamente, PEREIRA, Eliane Manso C. M. Goiânia, filha mais moça e bonita do Brasil. In: BOTELHO, T. R. (org.). Goiânia: cidade pensada. Goiânia/GO: Ed. UFG, 2002, p. 13-70; PINTO, Rubia-Mar Nunes. Caminhos cruzados: a cidade e a escola na história da educação em Goiás na primeira república. In: BARRA, Valdeniza Maria Lopes da (org.). Estudos de história da educação de Goiás (1830-1930). Goiânia: PUC-GO, 2011, p. 230.

${ }^{111}$ NETO, José Moraes dos Santos. Visão do jogo: primórdios do futebol no Brasil. São Paulo: Cosac \& Naify, 2002, p. 35.
} 
adversidades". ${ }^{112}$ O processo de difusão e desenvolvimento do futebol em Goiás, mesmo se tardio se comparado a centros urbanos como Rio de Janeiro ou São Paulo, foi o resultado de relacionamentos e influências vindas não apenas de regiões metropolitanas, mas especialmente de outras cidades do hinterland. De Campinas, Ribeirão Preto, Uberaba ou Araguari partiram boa parte dos estímulos para a prática do futebol em Goiás. Grandes centros metropolitanos, nesse caso, não necessariamente funcionaram como modelo ou polo irradiador para práticas esportivas. ${ }^{113}$

Aqui, menos que negar o papel que grandes metrópoles eventualmente exerceram sobre o cenário esportivo goiano, trata-se, em outro sentido, de relativizar tais influências, que não foram, afinal, tão grandes ou tão frequentes assim. Em Goiás, referências aos acontecimentos esportivos do Rio de Janeiro ou de São Paulo foram raros e não parecem ter ocupado papel importante no imaginário esportivo da região no período de que trata este estudo. Nessa época, o desenvolvimento do esporte em Goiás parece ter sido fundamentalmente protagonizado por agentes locais, que acomodaram, assimilaram e utilizaram ideias e concepções sobre a nova prática de maneira autônoma, em certo sentido peculiar, em ritmo particular e à luz de interesses que lhes eram próprios. A peculiar forma com que jornais como Voz do Povo ou Novo Horizonte, politicamente ligados a impulsos de transformação que afetavam Goiás naquele período, manipularam simbolicamente os esportes é de certo modo reveladora desses usos sociais possíveis. Os goianos, nesse sentido, não estiveram apenas a receber tais influxos de modo inerte e passivo. Foram literalmente protagonistas de suas próprias histórias.

Artigo recebido para publicação em 28/06/2012

Artigo aprovado para publicação em 19/05/2013

\footnotetext{
${ }^{112}$ DIAS, Cleber. História do esporte no sertão brasileiro: memória, poder e esquecimento. Materiales para la Historia del Deporte, Sevilla, n. 10, p. 24-36, sep. 2012.

${ }^{113}$ Para uma interessante crítica ao modelo teórico costumeiramente adotado nos estudos históricos do esporte em regiões de fronteira, ver HOWELL, Colin; LEEWORTHY, Daryl. Borderlands. In POPE, S. W; NAURIGHT, John. (eds.). Routledge companion to sports history. New York: Routledge, 2009. Para uma crítica do mesmo tipo no âmbito da historiografia brasileira, ver DIAS, Cleber. Esporte e cidade: balanços e perspectivas. Tempo, Niterói, vol. 19, n. 34, p. 29-40, 2013.
} 